\title{
PLURALISTIC AND MULTICULTURAL EDUCATION IN THE INDONESIAN SCHOOLS
}

\author{
Paul Suparno \\ Sanata Dharma University \\ paulparno@gmail.com; suparno@usd.ac.id \\ https://doi.org/10.24071/ijiet.v1i1.328
}

\begin{abstract}
Indonesia consists of many islands, cultures, ethnicities, and religions. This country will be strong if its people would like to live and work together peacefully. It can be done if they accept their differences and want to work together as one nation. The spirit should be taught since the elementary schools until universities. Thus, the curriculum, teachers, and teacher training institutes should be pluralistic and multicultural. Indonesian schools should provide and improve the pluralistic and multicultural spirit and environment, because there are still many obstacles in these matters.
\end{abstract}

Keywords: pluralistic and multicultural education, Indonesian schools, curriculum

\section{Introduction}

Indonesia consists of more than 300 ethnic groups, cultures, religions, and faiths. Indonesia is a multicultural and pluralistic nation. This country will become strong only if its people are able to accept their differences, live together and work together peacefully.

The Country has Pancasila philosophy and UUD 1945 as its constitution and become its basic for living together as a nation. We have Bhineka Tunggal Ika as our vision that we are many but one. We are different but we want to live together as one nation. That spirit will be stronger if we can accept and live together in differences.

The spirit of accepting the differences does not automatically emerge, but they need to be built and developed. Through pluralistic and multicultural education, we are able to help young students to be aware of the importance of accepting, living and working together as one family. This kind of education should be done since the elementary schools and continue until they study in the university.

This paper discusses some aspects of pluralistic and multicultural education, such as a pluralistic curriculum, teachers, teachers training institutes, intercultural experiences, and how to implement them in Indonesian schools.

\section{Pluralistic and Multicultural Education}

Pluralistic education or multicultural education is defined as a perspective that recognizes (a) the political, social, and economic realities that individual 
experience in culturally diverse and complex human encounters; and (b) the importance of culture, race, sexuality and gender, ethnicity, religion, socioeconomic status, and exceptionalities in the educational process (NCATE, 1986, in Hernandez, 1989: 4).

Most teachers know pluralistic and multicultural education more as education that accepts pluralistic culture. For them, education must stress the importance of student culture and honor their different cultures. The diversity of culture is known and accepted even is more developed. So it is clear that pluralistic education is education that accepts and develops the diversity among student because of their culture, religion, economic, and ethnicity. The purpose is that the young students are able to live and work together in their diversity.

According to Grant and Sleeter (1989: 143-144), multicultural education has two main problems: (1) give the same opportunity for education to all students and (2) pluralistic education. First, each student has to get the same opportunity to success in their education without discrimination. To help them success in their study, the weak and disabled students should be helped more according to their culture and situation. By considering the pluralistic situation, each student can be developed optimally.

Students should be incouraged to see and understand other cultures, so they can accept and honor the different cultures. So, it is important not to hide the different cultures, or make all the cultures as one culture. In the Indonesian new regime (Order Baru), we experienced that the government tried to erase the diversity and pushed the same national culture for all. In this condition it seems that the country is likely peaceful, but actually there are many conflict inside andmany people feel afraid.

The Indonesian law of education (Sisdiknas, 2003) says that the Indonesian education is not discriminative. The national education process is democratic and non dicriminative and also honors the pluralistic nation (verse 4). The Sisdiknas also says that the Indonesia education emphasizes the quality for each student without discrimination. Disable, special, or gifted students are educated differently according to their situation. In this document, it is clear that Indonesianeducation is pluralistic in which each student will be educated according to their situation.

According to Giselbrecht (2009: 12), pluralistic education is aboutvalidating students and letting them know that they have the same opportunity in the academic study. Pluralistic approaches to languages and cultures are democratic concepts which acknowledge the right to diversity of all cultural varieties. Pluralistic concepts support attitudes of openness, tolerance and understanding towards the cultures, social structures and values of other communities. In the context of education, pluralistic ideas can be put into practice by the development of a global view of learning and teaching of language and culture. 


\section{Strategy for Pluralistic and Multicultural Education}

To develop the pluralistic and multicultural education in this country, some strategies should be done such as: pluralistic curriculum, teaching, teachers, teacher education, situation of school, and some intercultural experiences.

\section{Pluralistic Curriculum}

The curriculum should be pluralistic curriculum. The curriculum content should improve student to accept diversity and communicate with other different cultures. That is why, students should learn the different culture in their schools. Because Indonesia has many songs, dances, food, ornaments, shirts, and languages, so students should learn about different food, music, dances, behavior, languages, culture values, how they think, behave, and communicate. By learning their different cultures students will know other cultures and will be easier to accept their different friends.

The way teachers teach students should be pluralistic. Teachers shouldknow the student's situation and cultures, so they are able to help students according to their situation. Teachers should use several approaches in their teaching. For example, they give variety of examples according to gender, cultures, and students' situation. Teachers should teach students using multiple intelligences, so the students are able to understand the material content easily. When teachers ask students to make a group or work together in small group, the group should consist of different students from different cultures. By making a group from different cultures, students will learn how to live and work together with others peacefully.

The books used in the classroom should multicultural. They have to be free from discrimination, free from bias gender, ethnic, classes, age, religion, and minority. Sometimes, several books in their explanation or in their example have bias meaning and omit some factors that will distract students' knowledge about pluralistic and multicultural spirit. It is better if each shool evaluates every textbook that will be used in teaching learning process, so it will be free from discrimination.

Classroom situation should be arranged according to multicultural relation among teachers and students. Classroom decoration should be managed according to multicultural values. For example, in each classroom we can put pictures of different heroes from different islands, pictures of different cultures such as foods, islands, statues, dances etc.

In the Indonesia curriculum (Kurikulum 2013) there is centralized curriculum that is decided by the central government. But there are also some local subject matters that should be decided by the local government. The local subject matters give opportunity for students to learn about their local values, skills, and cultures.

It is better if the evaluation is also multicultural. It means that there are several models of evaluation, not only one evaluation model. The evaluation should be multicultural, used many kind methods and cope with students' different cultures. 
The multicultural curriculum should provide several experiences for students to see and to have experiences about other cultures. For example, students have a trip to go to other islands that have different cultures. Studentslive in different cities, islands, provinces that have different cultures. By experiencing different cultures, they will be more open and understand the different people that have different cultures, religions, etnics. Schools providetheir students to play games with students from different schools that have different cultures, religions. Sometimes it will be better students do a project together with students from different schools. If students from different schools have oportunity to meet together, to play together, and to do project together, they will be more understand each others and they will be easy to work together. It willbe helpful if there is oportunities for students from different schools learn in different schools as exchange students.

\section{Multicultural Teachers}

One of the most important in the pluralistic and multicultural education is the teachers. The teachers should be pluralistic in their teaching, approaches, and style of living and communicating with students.

All teachers should pluralistic and multicultural. They should know how to be pluralistic teachers in the pluralistic situation. They should accept diversity, honor all students and know how to teach and evaluate. They should manage their teaching pluralistically. Teachers should stress diversity in their teaching learning, give some examples how to live together peacefully.

Teachers have to respect all different students; they do not discriminate against students according their cultures and gender. They teach using different culture so students will know the other culture and learn about it.

Teachers should know student situation and their cultures. They have to know student habits, values, families, languages, religion, health, what is their purpose of learning, hobby, media, environment, etc. So, it is better if teachers study about student situation and environment. By knowing student situation teachers are able to help students better.

Some teachers do not know their students and their backgrounds. Many teachers like to teach in the same ways and same method for different students. Some of them like to push students to behave the same and not allow differences in their classroom. Even some teachers don't like if students answer or do their task different with the teachers answer. This situation sometimes makes students unhappy in their classroom.

Giselbrecht (2009) says the importance of pluralistic textbooks. Since these concepts are very new they will not be included in most current textbooks. Therefore, it is recommendable that teachers have access to additional materials. The internet, in general, represents a valuable source. There are several internet websites featuring information and activities which support pluralistic approaches.

The most important things to help students improve their multiculural spirit is teachers' example. Students everyday see and live with their teachers. They learn from their teachers how they behave, how they act as pluralistic or multiculurreal educators or not. If students everyday experience that their teachers 
are discriminative or do not honor students from different culture, students will follow those ecamples. So, to improve multicultural education in schools, teachers should become good examples.

\section{Teacher Training Institute}

Teacher training institutes are very important. They have to have pluralistic programs that are not discriminative. They should train and facilitate student teachers on pluralistic approaches in teaching learning.

Teacher training institutes should help students to develop and improve their knowledge and awareness about pluralistic and multicultural education. The institutes should have a center for learning and teaching in pluralistic and multicultural situation. The center will help students and teachers who want to learn and develop their understanding about pluralistic education.

In this center some experts and researchers are able to work together in developing program, methods, strategy, and books that stress on pluralistic education. In this way, the center is able to give support and material to teachers and student teachers around this country.

Indonesia has many teacher trainning institutes such as FKIP (Faculty of Teaching and Education). In this institutes students learn to be teachers either for elementary schools, junior high schools, or senior high schools. The institutes stress on subject matter and pedagogy for teachers. In some institutes students learn multiculture education, multiculture teaching and learning, but in someinstitutes the multiculture and pluralistic environment have not been yet developed. So, all teacher training institutes schould provide and improve their multiculture and pluralistic education and environment.

\section{Intercultural Experiences}

According to Giselbrecht (2009), the most important to develop students pluralistic and multicultural sense and habit is to give students intercultural experiences. Students should be given opportunities and experience about authentic intercultural contacts. In this way, they can make use of their pluralistic skill and extend their plurilingual and pluricultural repertoire.

There are various ways in which students could put their pluralistic skills into practice in the real world. Because Indonesia consists from many islands that has different cultures, students can be encouraged to correspond with pen friends from different islands. They can communicate with friends from different cultures and islands using internet or gadget.

Visiting, traveling, and going to other island that have different cultures and language in Indonesia are very important to understand better other cultures. Students don't learn different cultures from books only, but from their real experience about other cultures. By visiting other islands, students are able to see, meet, talk, communicate with different people from other culture. These real experiences will give them more deep understanding about other people.

Living in different islands or places with different cultures is very important too. Students are able to live in other different cultures, so they have experience living together in peaceful situation with other people. For example, High school 
students from Jakarta (capital city) live in Wonosari (small villages). By doing so, they learn how people in Wonosari live and work for their living. Students have experiences living in small village, doing agricultures, and meet students from small villages. In some experiences, most students were happy and they were encouraged to help the village students as sisters. Most students learned to honor and appreciate village people values.

Meeting, playing, and doing same project with different students from different schools that have different culture and background are also helpful for improving multicultural education. In Indonesia there are several kind of schools that have different background and values such as public schools, Islamic schools, national schools, Christian schools, catholic schools, Hindu schools, and conglomerated schools. Until now, some schools don't know and communicate together, they are doing their own jobs and education. It should be better is they improve their communication by doing project together playing games together, or have same program that they do together. For example, students from Catholics schools can meet and play together with students from Muhammadiyah Schools, or Public schools. Students from Hindu schools can do same project with national schools or different religion schools.

\section{Some Handicap of Multiculture Education}

There are many handicaps or obstacles for multiculture or pluralistic education in Indonesia. Some obstacles are as followed:

- Discriminative situation in some schools or places that divide students begining elementary schools to high schools not to communicate with different students from different cultures and religions.

- Some teachers don't honor different peoples in front of students, so students learn bad example from their teachers;

- Closed culture, not open minded, so students don't like to contact with other people.

- Some parents don't allow their sons to play together with other kids from different cultures or background;

- Some teachers are discrimintive and not multicultural. They have no pluralistic spirit in their life.

\section{Conclusion}

Pluralistic and multicultural education is very important for Indonesia because this country consists of many different culture, religion, ethnics, and social situation. The pluralistic and multicultural education will improve student character that will easily accept other different friends.

The pluralistic and multicultural education will develop if their teachers are multicultural and pluralistic. Teachers should give good example on multicultural spirit to students. And to help teachers become pluralistic, teacher training institutes should be professionnal in trainning teachers on pluralistic and multicultural education. The most important in helping students to have more pluralistic and multicultural habit in their lives is by giving them experiences contact with other culture and live in the different culture places. There are still 
many obstacles that should be erased in the Indonesian schools to be more pluralistic and multicultural education.

\section{References}

AACTE. (1992). No one model American: A Statement on multicultural education. In Ryan and Cooper, Kaleidoscope: Reading in education. Boston: Houghton Mifflin Company, pp. 440-441.

Giselbrecht, M. (2009). Pluralistic approaches: A Long overdue paradigm in education. In Scottish Languages Review, Issue 20, autumn 2009, 11-20, ISSN 1756-039X.

Gollnick, D. \& Chin, P. (2013). Multicultural education in a pluralistic society. Upper Saddle River, NJ: Pearson Education.

Grant, C. A., \& Sleeter, C. E. (1989). Turning on learning: Five approaches for multicultural teaching plans for race, class, gender, and disability. Columbus: Merrill.

Hernandez, H. (1989). Multicultural education. Columbus: Merrill Publishing Company.

Ravitch. (1992). Multicultural education. In Ryan and Cooper, Kaleidoscope: Reading in education. Boston: Houghton Mifflin Company, pp. 442-448.

UURI no 20, Th 2003 ttg Sistem Pendidikan Nasional (Sisdiknas). 